\title{
Overview Hazard Analysis for the H2Fuel Bus Program
}

by

\author{
G. L. Hovis
}

Westinghouse Savannah River Company.

Savannah River Site

Aiken, South Carolina 29808

This paper was prepared in connection with work done under the above contract number with the U.S. Department of Energy. By acceptance of this paper, the publisher and/or recipient acknowledges the U.S. Government's right to retain a nonexclusive, royalty-free license in and to any copyright covering this paper, along with the right to reproduce and to authorize others to reproduce all or part of the copyrighted paper. 


\section{DISCLAIMER}

This report was prepared as an account of work sponsored by an agency of the United States Government. Neither the United States Government nor any agency thereof, nor any of their employees, makes any warranty, express or implied, or assumes any legal liability or responsibility for the accuracy, completeness, or usefulness of any information, apparatus, product, or process disclosed, or represents that its use would not infringe privately owned rights. Reference herein to any specific commercial product, process, or service by trade name, trademark, manufacturer, or otherwise does not necessarily constitute or imply its endorsement, recommendation, or favoring by the United States Government or any agency thereof. The views and opinions of authors expressed herein do not necessarily state or reflect those of the United States Government or any agency thereof.

This report has been reproduced directly from the best available copy.

Available to DOE and DOE contractors from the Office of Scientific and Technical Information, P.O. Box 62, Oak Ridge, TN 37831; prices available from (615) 576-8401.

Available to the public from the National Technical Information Service, U.S. Department of Commerce; 5285 Port Royal Road, Springfield, VA 22161. 


\section{DISCLAIMER}

Portions of this document may be illegible in electronic image products. Images are produced from the best available original document. 


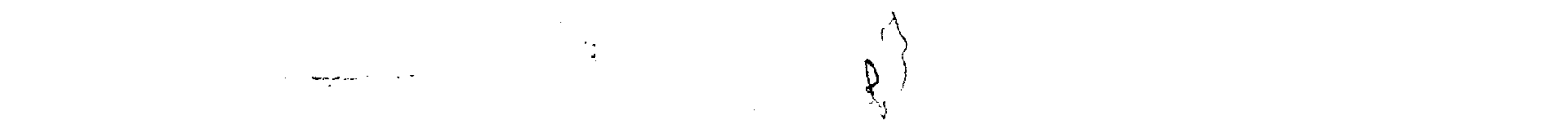

OVERVIEW HAZARD ANALYSIS FOR

THE H2FUEL BUS PROGRAM (U)

G.L. Hovis

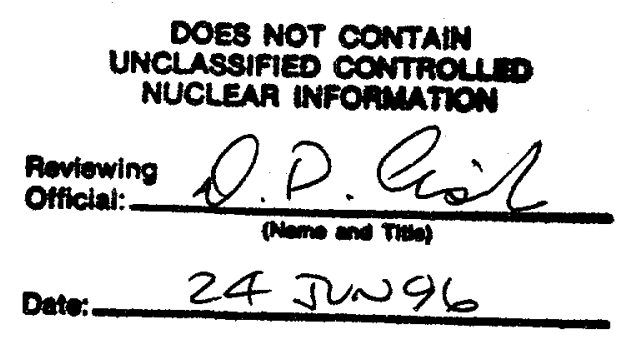

Westinghouse Savannah River Company

Engineering and Construction Services Division

Aiken, SC 29808

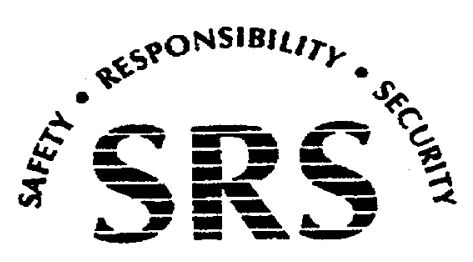




\section{G.L. Hovis}

Publication Date: June 18, 1996

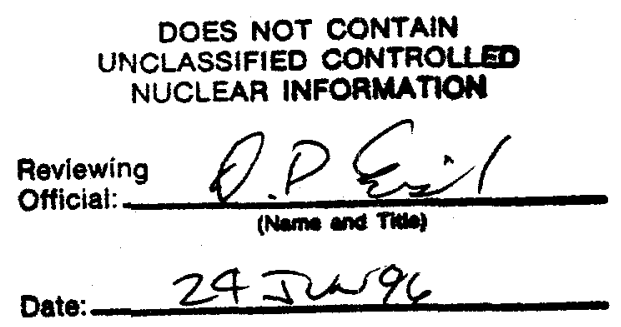

Westinghouse Savannah River Company

Engineering and Construction Services Division

Aiken, SC 29808

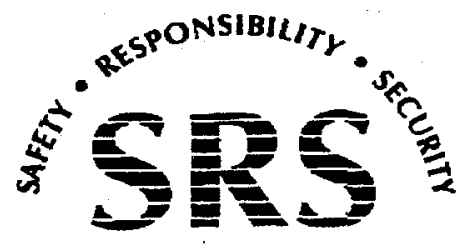


WSRC-RP-96-337, Rev. 0

This Page Intentionally Blank 
Report Title: Overview Hazard Analysis for the H2Fuel Bus Program (U)

Revision: 0

Date: June 18, 1996

Author: G.L. Hovis

Key Words: Hazard Analysis, Hydrogen Bus, Electric Bus

H2Fuel Bus Hazard Analysis Team:

(All team members employees of Westinghouse Savannah River Co, WSRC)
G.L. Hovis
Team Lead, Environmental \& Hazard Analysis
D.A. Coutts
Site Fire Protection
S.R. Salaymeh
Manager, Environmental \& Hazard Analysis
I.J. Paik
Environmental \& Hazard Analysis
J.K. Thomas
DBA/Phenomena Analysis
T.A. Long
A.G. Sarrack
DBA/Phenomena Analysis
D.A. Eisele
Risk Analysis
Consequence Analysis

\section{APPROVALS:}
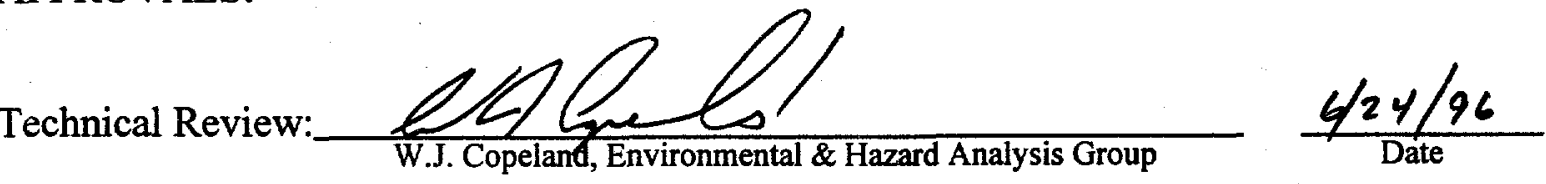

Approval:

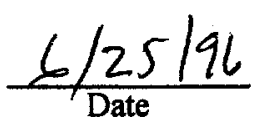

Approval:

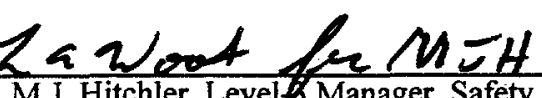


This Page Intentionally Blank 


\section{Table of Contents}

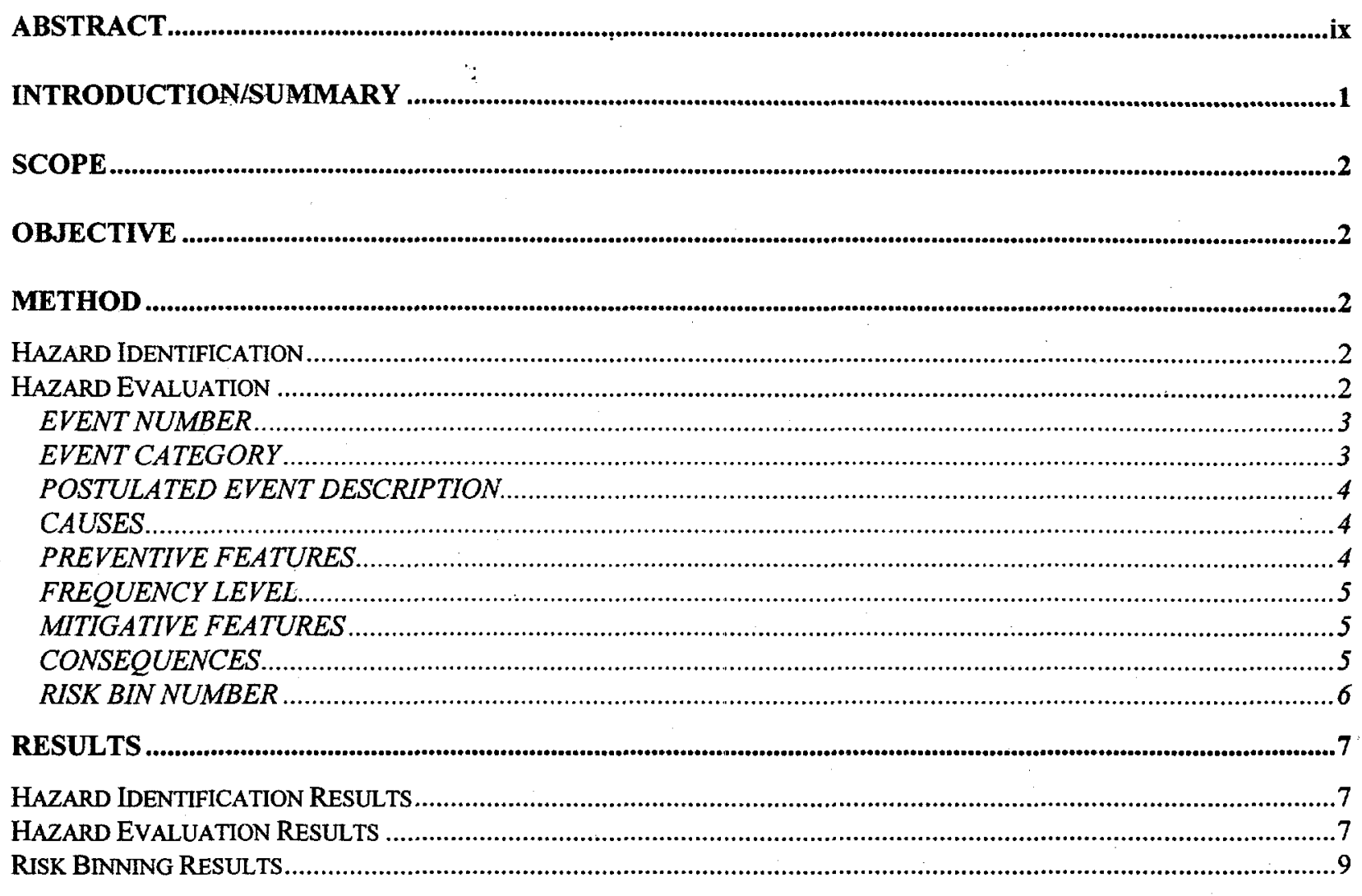

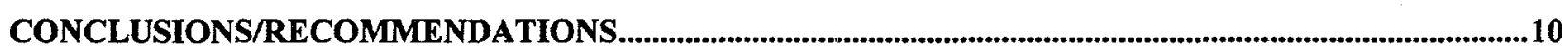

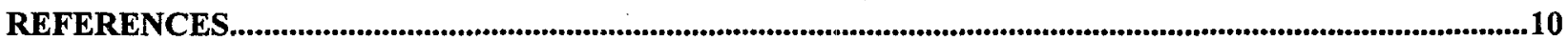

TABLE 1. FREQUENCY EVALUATION LEVELS ................................................................................................12

TABLE 2. CONSEQUENCE EVALUATION LEVELS...........................................................................................12

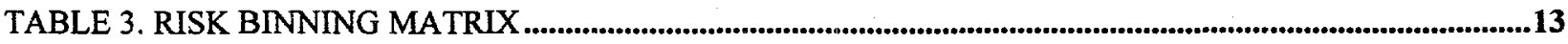

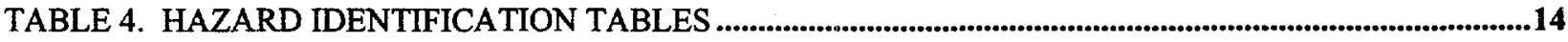

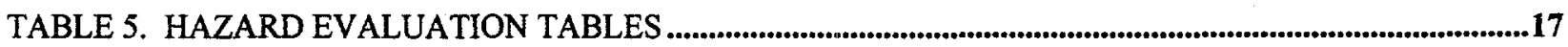


WSRC-RP-96-337, Rev. 0

This Page Intentionally Blank 


\section{ABSTRACT}

The H2Fuel Bus project is a joint development effort to produce a safe, near-zero emission, 32 passenger bus that is propelled by electric power with continuous on-board hydrogen powered battery recharging. A key initiative in the hydrogen bus development effort is a rigorous evaluation of operational safety.

Westinghouse Savannah River Co., the prime contractor at the Department of Energy's Savannah River Site, has developed a hazard analysis methodology designed to provide a systematic, comprehensive identification and evaluation of hazards. Although originally developed to support nuclear/chemical facility safety basis documentation, the SRS Methodology has widespread applicability to operations and/or systems that utilize hazardous materials and energy. This methodology was used to perform an overview hazard analysis for the H2Fuel Bus project to focus attention on those hypothetical circumstances that pose the greatest threat to the populace and property.

The hazard analysis yields a listing of all known H2Fuel Bus hazards, postulated accident scenarios describing possible hazardous releases or conditions, an assessment of the scenarios in terms of frequency of occurrence and consequence, and "binning" in frequency-consequence space to assess the relative severity of postulated scenarios. 


\section{INTRODUCTION/SUMMARY}

The H2Fuel Bus project is a joint development effort to produce a safe, near-zero emission, 32 passenger bus that is propelled by electric power with continuous on-board hydrogen powered battery recharging. A key initiative in the hydrogen bus development effort is a rigorous evaluation of operational safety.

The hazards associated with refined fossil fuels (gasoline, diesel, propane, etc.) is well documented. Design safety features in conventional vehicles mitigate the impact of these hazards to a level that is acceptable to the general public. However, experience with hydrogen power is, for the most part, confined to laboratory and limited-use applications. For this reason, the Department of Energy in association with the H2Fuel Bus project Team has commissioned the Savannah River Site to lead a thorough hazard evaluation centered on the use of hydrogen fuel as an alternative power source for mass-transit.

Westinghouse Savannah River Co., the prime contractor at the Department of Energy's Savannah River Site, has developed a hazard analysis methodology designed to provide a systematic, comprehensive identification and evaluation of hazards. Although originally developed to support nuclear/chemical facility safety basis documentation, the SRS Methodology has widespread applicability to operations and/or systems that utilize hazardous materials and energy. This methodology was used to perform an overview hazard analysis for the H2Fuel Bus project to focus attention on those hypothetical circumstances that pose the greatest threat to the populace and property.

The hazard analysis yields a listing of all known H2Fuel Bus hazards, postulated accident scenarios describing possible hazardous releases or conditions, an assessment of the scenarios in terms of frequency of occurrence and consequence, and "binning" in frequency-consequence space to assess the relative severity of postulated scenarios.

A total of 27 scenarios were postulated. Three of the 27 scenarios were binned in the "high" risk category. They are: (1) a general combustible fire that consumes the bus and ignites the hydrogen; (2) a collision that causes rapid hydrogen leak and simultaneous ignition sources; and (3) personnel asphyxiation due to leaked, accumulated hydrogen. Additional phenomenological analyses are recommended for these three events to make a deterministic assessment of risk.

NOTE: The information in this report is not an endorsement, recommendation. or license for safe operation. This analysis simply performs and documents a qualitative, comprehensive identification and evaluation of hazards. 
WSRC-RP-96-337, Rev. 0

\section{SCOPE}

The scope of this task was to perform a high-level or "overview" hazard analysis to assess the hazards associated with the proposed Hydrogen Bus prototype. The overview analysis is a largely qualitative process that considers unmitigated, reasonable worst-case releases of the hydrogen bus hazards.

\section{OBJECTIVE}

The objective of this analysis was to focus attention on those hazards, systems, and release scenarios that pose the greatest concern in terms of postulated frequency and consequence. This information is used to (1) make recommendations for additional phenomenological analyses and (2) establish the scope of a "component-level" hazard analysis which assesses the function of specific design features in preventing and/or mitigating the impact of hazardous conditions and/or releases. Note, the component-level analysis is currently being performed and is the subject of future documentation.

\section{METHOD}

The following sections present the hazard analysis methodology used to identify and evaluate the hydrogen bus hazards. The methodology is based on guideline 2.1.2 of Reference 1.

\section{Hazard Identification}

Hazard identification is a comprehensive, systematic process by which all known hazards (hazardous materials and energy) associated with bus operations are identified and recorded. Hazard identificationis performed by a team of functional experts (design, projects, operations, hazard/safety, etc.).

Hazard identification Tables, used to document the results of Hazard Identification, are a useful "checklist" and guide for performing this phase of the hazard analysis. Hazard identification Tables are filled-out by the team during the hazard identification process.

\section{Hazard Evaluation}

The hazard evaluation constitutes the primary focal point of the hazard analysis. Hazards are characterized in the context of actual operations and processes by considering feasible release mechanisms (or events), estimating initiating event frequency, estimating consequences of the release, and identifying any preventors and mitigators. The purpose of Hazard evaluation is to ensure a comprehensive assessment of hazards and focus attention on those events that pose the greatest risk to the populace and/or property. 
The scope of hazard evaluation includes:

- All aspects of facility process and modes of operation including startup, shutdown, refueling, and routine maintenance that is considered part of normal operations.

- Natural phenomena (e.g. earthquakes, tornadoes, straight-line winds) and external events (e.g. vehicular impact).

- The entire spectrum of possible events for a given hazard in terms of both frequency and consequence levels.

Using the results of hazard identification as a basis, the hazard analysis team considers detailed information regarding hazardous material and energy sources in the context of actual operations to develop specific release events. Event categorization, identification of event cause(s), assignment of event frequency and consequence level, identification of mitigative and preventive features, and risk binning are tasks conducted by the hazard analysis team during Hazard evaluation.

Information related to hazard evaluation is collected and organized in "Hazard Evaluation Tables." These tables are a useful guide for performing hazard evaluation and they provide an effective format for documenting hazard evaluation results. Information in these tables is organized into the following categories:

$\begin{array}{ll}\text { - } & \text { Event Number } \\ \text { - } & \text { Event Category } \\ \text { - } & \text { Postulated Event Description } \\ \text { - } & \text { Causes } \\ \text { - } & \text { Freventive Features } \\ \text { - } & \text { Mitigative Features } \\ \text { - } & \text { Consequences } \\ \text { - } & \text { Risk Bin Number }\end{array}$

Additional detail and pertinent methodology information regarding each of the Hazard Evaluation Table categories is provided in the following sections.

\section{EVENT NUMBER}

Events are numbered to provide each with a sequential reference.

\section{EVENT CATEGORY}

Events are categorized according to the nature of the postulated release mechanism. The categories are as follows:

- E-1 Fire

- E-2 Explosion 
- E-3 Loss of Containment/Confinement

- E-4 Direct Hazard Exposure

- E-5 External Hazards.

- E-6 Natural Phenomena

- E-7 Other

Events are categorized according to the event description rather than the event cause. For example, a fire might be a postulated event that is caused by an external event. This event would fall under category E-1 (Fire) rather than E-5 (External Event).

\section{POSTULATED EVENT DESCRIPTION}

A brief description of a postulated event is given in this column of the Hazard Evaluation Tables. The event description clearly defines the nature of the event. It includes the type of event, its location, hazard source, affected system(s) or equipment, any interaction with other system(s), equipment, and/or hazards, and any pertinent operating characteristics.

Using the Hazard identificationTables as a basis, the hazard analysis team develops event scenarios wherever a potential exists for a release of hazardous energy and/or material. The scenarios cover the entire spectrum of possible events for a given hazard; from small consequence events, for which procedures or equipment is acknowledged to provide adequate protection, to reasonable worst-case conditions. Unlike "worst-case," "reasonable worst-case" does not necessarily consider every parameter in its most unfavorable state.

\section{CAUSES}

A cause specifically states the failure, error, operational, and/or environmental condition that initiated the postulated event. Causes are synonymous with initiating events and therefore need to be clearly identified to support frequency evaluation. The Hazard identificationTables are used as a guide in developing specific causes for release events.

\section{PREVENTIVE FEATURES}

A preventive feature is any feature that could readily be expected to act to prevent the release of hazardous material to an unwanted location, thus reducing the frequency of the associated release event. The selection of such features is made without regard to any possible pedigree of the feature such as procurement level or current classification. These might include engineered features (e.g. structures, systems, components, etc.), administrative controls (e.g. procedures, policies, programs, etc.), natural phenomena (e.g. ambient conditions, buoyancy, gravity, etc.), or inherent features (e.g. physical or chemical properties, location, elevation, etc.) operating individually or in combination. Preventive features are those which are assumed to be operable prior to an event and are not required to be operable during the event or post event. 


\section{FREQUENCY LEVEL}

Event frequency evaluation is a qualitative or quantitative process that involves assigning a frequency level to each event in the Hazard Evaluation Tables. Frequency levels and descriptions are summarized in the Frequency Evaluation Levels in Table 1.

The hazard analysis team determines which qualitative frequency level is appropriate for a particular event. This determination is based on the event's root cause(s) and may be either qualitative or quantitative. The frequency level is recorded in the Hazard Evaluation Tables according to the Table 1 lettering scheme. Uncertainties in frequency levels are accommodated by erring in the conservative direction from best-estimate values.

When evaluating event frequency, credit may be taken for inventory controls limiting the amount of hazardous materials. Credit may also be taken for the ability of people to react to obvious hazardous conditions and evacuate; This of course invokes the assumptions that the people are physically able to evacuate, and that an evacuation route is available immediately following the hazardous condition. Crediting any other structure, system, component (SSC), or administrative control for its preventive properties is discouraged. In the case that a preventive feature or assumption is credited during frequency determination, that feature must be listed and highlighted (or underlined) in the Hazard Evaluation Tables for completeness.

\section{MITIGATIVE FEATURES}

Mitigative features are any feature that are readily expected to act to reduce the consequences associated with the release of hazardous material to an unwanted location for a particular event. The identification of such features is made without regard to any possible pedigree of the feature such as procurement level or current classification. Mitigative features are those which are assumed to be operable during an event or post event, and are not required to be operating prior to the event initiation. Therefore, mitigative features must be capable of withstanding the environment of the event. These might include engineered features (e.g. structures, systems, components, etc.), administrative controls (e.g. procedures, policies, programs, etc.), natural phenomena (e.g. ambient conditions, buoyancy, gravity, etc.), or inherent features (e.g. physical or chemical properties, location, elevation, etc.) operating individually or in combination.

\section{CONSEQUENCES}

Event consequences are documented by specifying the impact on the "receptors" (described below). Any potential impact of consequences on other systems is also documented in this column of the Hazard Evaluation Tables.

For hazard analysis purposes, consequences are defined as the impact at specified receptor locations. Consequences are a function of the type and characteristics of the hazard, the quantity released, the release mechanism, relative location of the release, and any relevant transport characteristics. The hazard analysis team utilizes its discretion, expertise, and knowledge of the relevant hazards to select the appropriate consequence level. Much like frequency evaluation, 
the hazard analysis team is encouraged to err in the conservative direction, especially for those events with consequences at the high end of a given level.

Consequences are evaluated for two receptors, populace and property. Tables 2 summarizes the consequence levels for the specified receptors.

When evaluating event consequences, credit may be taken for inventory controls limiting the amount of hazardous material. Credit may also be taken for the ability of people to react to obvious hazardous conditions and evacuate; This of course invokes the assumptions that the people are physically able to evacuate, and that an evacuation route is available during or immediately following the hazardous condition. Crediting any other structure, system, component (SSC), or administrative control for its mitigative properties is discouraged. In the case that a mitigative feature or assumption is credited during consequence determination, that feature must be listed and highlighted (or underlined) in the Hazard Evaluation Tables for completeness.

The Hazard Evaluation Tables should provide, for each of the postulated release events, the impact of the event on the receptors. This information is documented in the column labeled "Impact on Receptors (guideline used)" under the "Consequence" heading of the Hazard Evaluation Tables. To lend completeness to the hazard analysis task, the hazard analysis team may consider any potential impact on other systems and list these in the Hazard Evaluation Tables in the "Impact on Other Systems" columns under the "Consequence" heading.

\section{RISK BIN NUMBER}

.Using event frequency and consequence levels the hazard analysis team "bins" events in frequency-consequence space to assess relative risk. The objective of risk binning is to focus attention on those events that pose the greatest risk to the specified receptors. Higher risk events might be candidates for additional analysis.

Table 3 gives the risk binning matrix. In this table, bins are defined by a rectangular matrix in frequency-consequence space. Each bin is uniquely numbered, but numbering is for identification purposes only (i.e. risk severity is not proportional to the magnitude of the bin label). The darker shaded bins, (i.e. 1,2, and 4), represent combinations of frequency and consequence that indicate a "high" risk. The diagonal, (i.e. bins 3, 5, and 7) represent moderate risk. Bins 6,8 , and 9 represent "low" risk, and bins 10,11 , and 12 correspond to "negligible" risk..

The Hazard Evaluation Tables provides, for each of the postulated release events, a risk bin number. Events are binned using event frequency and the higher of the consequence values at the two receptors. For example, an event with an event frequency of unlikely (U), a populace consequence of moderate $(\mathrm{M})$, and a property consequence of high $(\mathrm{H})$, would be assigned a risk bin 4 (frequency- $\mathrm{U}$, consequence- $\mathrm{H}$ ) rather than risk bin 5 (frequency- $\mathrm{U}$, consequence- $\mathrm{M}$ ). This 
WSRC-RP-96-337, Rev. 0

is an additional level of conservatism in the binning approach that aids in focusing attention on the highest risk scenarios.

\section{RESULTS}

The results of the overview hazard analysis for the hydrogen bus is provided in the following sections. Results are provided for each of the three primary hazard analysis elements, i.e. hazard identification, hazard evaluation, and risk binning.

\section{Hazard Identification Results}

The hazard identification was performed by the H2Fuel Bus hazard analysis team on May 7 , 1996. The results of that effort are summarized in Table 4 (Hazard Identification Tables).

The hazard identification tables in Table 4 document all know hydrogen bus hazards. Identified hazards are indicated by the " $X$ " in each applicable column. These hazards are considered during the hazard evaluation to derive initiating events and release scenarios.

\section{Hazard Evaluation Results}

The hazard evaluation was performed by the H2Fuel Bus hazard analysis team on May 7, 1996. The results of that effort are summarized in Table 5 (Hazard Evaluation Tables).

A total of 27 scenarios were evaluated. A breakdown by event category is given below:

\begin{tabular}{llc} 
Category & Category Description & No.Events \\
\hline E-1 & Fires & 5 \\
E-2 & Explosions & 8 \\
E-3 & Loss of Confinement/Containment & 4 \\
E-4 & Direct Hazard Exposure & 2 \\
E-5 & External Hazards & 2 \\
E-6 & Natural Phenomena & 3 \\
E-7 & Other & 3
\end{tabular}

Identified preventive and mitigative features for each scenario is provided in the hazard evaluation tables (Table 5).

The purpose of the hazard analysis is to focus on those hazards or situations requiring the greatest level of control as opposed to an assessment of the adequacy of existing controls. In other words, this hazard analysis technique determines where the worst hazards are. It does not make an attempt to evaluate how well engineered safety systems or procedures serve to prevent and/or mitigate the effects of the hazard. Any excess conservatism in this technique is offset in 
the final step, risk binning, which looks at relative risk, not the absolute value of risk. The techniques used in making frequency and consequence assessments are described below:

Frequencies for events are evaluated using conservative, generic data. Vehicle accidents are based on US Department of Transportation (DOT) statistics (Ref. 2). General component failure rates (such as pipe / tank leaks) come from an SRS report on generic component failure rates (Ref. 3). SRS experience is used to estimate frequencies for some events, as reported in the SRS fault tree data base (Ref. 4).

External event frequencies are estimated by assuming severity levels of interest and using site reported frequencies (Ref. 5 and 6). In some cases, initiating events are taken from referenceable documents, but are reduced by conservatively estimating reduction factors for the specific accident of interest. For cases where the frequency of an event relies on unavailable data, the event is assigned to the "anticipated" frequency bin.

Consequences were evaluated for populace and property. The populace includes bus operating/maintenance personnel, customers (boarded and unboarded), and the surrounding population (immediate vicinity, both inside and outside surrounding vehicles). Property includes the bus and surrounding property (immediate vicinity vehicles, structures, and equipment).

Scenarios were evaluated for bounding consequences as described in the methodology section. During operations, the bus is assumed in the populace and property configuration described above, i.e. with driver, passengers, immediately surrounded by other vehicles and structures. Consequences were assessed using qualitative methods, i.e. a fire prompts egress and results in injuries or death and bus damage, whereas an explosion causes immediate loss of life and results in propagating collateral damage. 


\section{Risk Binning Results}

The 27 postulated events were binned as a function of event frequency and consequence. The results of risk binning are provided in the hazard evaluation tables (Table 5) in the column labeled "Risk Bin No.." The breakdown of scenarios by risk is given below:

\begin{tabular}{lcc} 
Risk & Risk Bin Numbers & No. Events \\
\hline High & $1,2,4$ & 3 \\
Moderate & $3,5,7$ & 10 \\
Low & $6,8,9$ & 9 \\
Negligible & $10,11,12$ & 5
\end{tabular}

Three events were binned under "High" risk, i.e. bin numbers 1, 2, and 4. Those events are discussed below:

\section{Event Number 4:}

This event is a fire involving general combustibles that initiates in electrical and/or mechanical systems outside passenger compartment. The bus is engulfed and the hydrogen is ignited. The resulting fire could cause loss of life and significant property losses. Causes of this event might be an electrical short, lightning, high temperature, a failure in the internal combustion engine, failure in the electrical heater equipment, improper maintenance, an external fire, or some unknown ignition source. Although the consequences of this event are high, the frequency is expected to be in the "Unlikely" range, i.e. $10^{-4}<\mathrm{f} \leq 10^{-2} / \mathrm{yr}$. The resulting risk bin is 4 . Preventive features for this event include design standards and operating procedures. Mitigative features are design standards, emergency exits, emergency equipment, and passenger evacuation.

\section{Event Number 18:}

This event is a personnel asphyxiation due to leaked accumulated hydrogen. Maintenance personnel and operators are the most likely receptor for this event. Consequences are loss of life, with minimal property damage. Causes of this event might be a mechanical or equipment failure, improper maintenance, or some external event that causes a hydrogen leak. Based on the initiators, the frequency of this event is in the "Unlikely" range, i.e. $10^{-4}<\mathrm{f} \leq 10^{-2} / \mathrm{yr}$. The resulting risk bin is also 4 . Design standards and maintenance procedures would act to prevent this event, and the hydrogen leak detection system would serve to mitigate the consequences.

\section{Event Number 20:}

This event involves a side impact collision that breeches the fuel system thereby rapidly releasing hydrogen under the bus. The collision is also expected to result in ignition sources due to exposed electrical equipment, sparks, etc. causing a deflagration or detonation. The resulting explosion could cause loss of life and significant property losses. Causes of this event might be operator error or mechanical failure. Although the consequences of this event are high, the frequency is expected to be in the "Unlikely" range, i.e. $10^{-4}<\mathrm{f} \leq 10^{-2} / \mathrm{yr}$. The resulting risk bin is 4 . Preventive features include bus design, design standards, traffic safety procedures, and 
maintenance procedures. Due to the rapid nature of the event, no mitigative features were identified.

\section{CONCLUSIONS/RECOMMENDATIONS}

The overview hazard analysis presented herein provides a systematic, comprehensive identification and evaluation of hazards associated with the hybrid hydrogen/electric bus. A largely qualitative, conservative assessment of the unmitigated impact of postulated release scenarios yielded several events that are considered "High" risk. It is recommended that additional analysis be conducted to make a more quantitative evaluation of risk for these events.

The design preventive and/or mitigative features (listed in the hazard evaluation tables) identify several notable design safety features. The hydrogen detection system is a necessary design feature, as it serves as a mitigator for a number accident scenarios (event no.s 12,13,14, 15, 16, 18 , and 19). The integrity of the passenger floor (or deck) is also an important mitigative design feature (event no.s 6, 7, 8, and 9) in shielding the passenger compartment during loss of confinement and fire scenarios. The relief protection at the hydride tanks serves both a preventive and mitigative function (event no.s $6,7,8,10$, and 11).

Administrative safety features are an essential part of safe H2Fuel Bus operations. Passenger evacuation following certain accidents (event no.s 1, 2, 3, 4, 5, and 9) is an important mitigative action. Since improper maintenance and operator error are identified as possible causes for many of the hazard evaluation table events, it is recommended that administrative controls (i.e. procedures, training, certification, etc.) be used to control maintenance and re-fueling activities.

\section{REFERENCES}

1. Safety Documentation Integrated Work Process Guidelines and Methods (U), WSRC-RP95-1001, Rev. 0, Westinghouse Savannah River Co., Aiken, SC, November 30, 1995

2. DW Harwood and ER Russell, Present Practices of Highway Transportation of Hazardous Materials, FHWA-RD-89-013, USDOT, 1990.

3. CH Blanton, et. al., Savannah River Site Generic Data Base Development (U), WSRC-TR93-262, June 1993.

4. Durant, W.S., Separations Facilities Fault Tree Data Bank (SEPR), 1993 Status Report (U), WSRC-TR-93-309, Westinghouse Savannah River Company, Savannah River Site, Aiken, SC, May 1993.

5. UCRL-53526, Revision 1. 
WSRC-RP-96-337, Rev. 0

6. HE Wingo, Development of Probabilistic Seismic Hazard Curve for DWPF at SRS, Rev. I (U), WSRC-TR-93-317, Revision 1, January 1994. 
Table 1. Frequency Evaluation Levels

\begin{tabular}{|c|c|c|}
\hline Acronym & Description & $\begin{array}{c}\text { Frequency Level } \\
\left(\text { year }{ }^{-1}\right)\end{array}$ \\
\hline A & Anticipated, Expected & $>10^{-2} / \mathrm{yr}$ \\
\hline $\mathrm{U}$ & Unlikely & $10^{-4}<\mathrm{f} \leq 10^{-2} / \mathrm{yr}$ \\
\hline EU & Extremely Unlikely & $10^{-6}<\mathrm{f} \leq 10^{-4} / \mathrm{yr}$ \\
\hline BEU & Beyond Extremely Unlikely & $\leq 10^{-6} / \mathrm{yr}$ \\
\hline
\end{tabular}

Table 2. Consequence Evaluation Levels

\begin{tabular}{|c|c|c|}
\hline $\begin{array}{c}\text { Consequence Level } \\
\text { (Abbreviation) } \\
\downarrow\end{array}$ & Populace & Property/Operations \\
\hline $\begin{array}{l}\text { High } \\
(\mathrm{H})\end{array}$ & $\begin{array}{l}\text { Prompt Fatalities, } \\
\text { Acute injuries - immediately life } \\
\text { threatening or permanently disabling, }\end{array}$ & $\begin{array}{c}\text { Damage }>\$ 10^{6} \\
\text { Vehicle Destroyed \& Surrounding } \\
\text { Property Damaged }\end{array}$ \\
\hline $\begin{array}{l}\text { Moderate } \\
\text { (M) }\end{array}$ & $\begin{array}{l}\text { Serious Injuries, } \\
\text { Permanent Disabilities, } \\
\text { Hospitalization Required }\end{array}$ & $\begin{array}{c}\$ 10^{4}<\text { Damage }<\$ 10^{6} \\
\text { Vehicle Destroyed, } \\
\text { Minor Impact on Surroundings }\end{array}$ \\
\hline $\begin{array}{l}\text { Low } \\
\text { (L) }\end{array}$ & $\begin{array}{l}\text { Minor Injuries, } \\
\text { No Permanent Disabilities, } \\
\text { No hospitalization }\end{array}$ & $\begin{array}{c}\text { Damage }<\$ 10^{4} \\
\text { Reparable Damage to Vehicle, } \\
\text { Significant Operational Down-Time, } \\
\text { No Impact on Surroundings }\end{array}$ \\
\hline $\begin{array}{l}\text { Negligible } \\
\text { (N) }\end{array}$ & Negligible Injuries & $\begin{array}{l}\text { Minor Repairs to Vehicle Required, } \\
\text { Minimal Operational Down-Time }\end{array}$ \\
\hline
\end{tabular}


Table 3. Risk Binning Matrix

\begin{tabular}{|c|c|c|c|c|}
\hline $\begin{array}{l}\text { Frequency } \rightarrow \\
\text { Consequence } \\
\downarrow\end{array}$ & $\begin{array}{l}\text { Beyond Extremely } \\
\text { Unlikely } \\
\leq 10^{-6} / \mathrm{yr}\end{array}$ & $\begin{array}{c}\begin{array}{c}\text { Extremely } \\
\text { Unlikely }\end{array} \\
10^{-6}<\mathrm{f} \leq 10^{-4} / \mathrm{yr}\end{array}$ & $\begin{array}{c}\text { Unlikely } \\
10^{-4}<\mathrm{f} \leq 10^{-2} / \mathrm{yr}\end{array}$ & $\begin{array}{l}\text { Anticipated } \\
>10^{-2} / \mathrm{yr}\end{array}$ \\
\hline High & & 7 & & \\
\hline Moderate & 10 & 8 & & \\
\hline Low & & 9 & 6 & \\
\hline Negligible & 11 & & 12 & \\
\hline
\end{tabular}

Key:

\begin{tabular}{|c|c|c|}
\hline \multirow{2}{*}{ 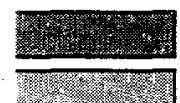 } & $\rightarrow$ & Risk Bins 1, 2, 4 (“High” risk) \\
\hline & $\rightarrow$ & Risk Bins 3,5,7 (“Moderate" risk) \\
\hline & & Risk Bins 6,8,9 ("Low" risk) \\
\hline & & Risk Bins 10,11,12 (“Negligible" risk) \\
\hline
\end{tabular}


Table 4. Hazard Identification Tables

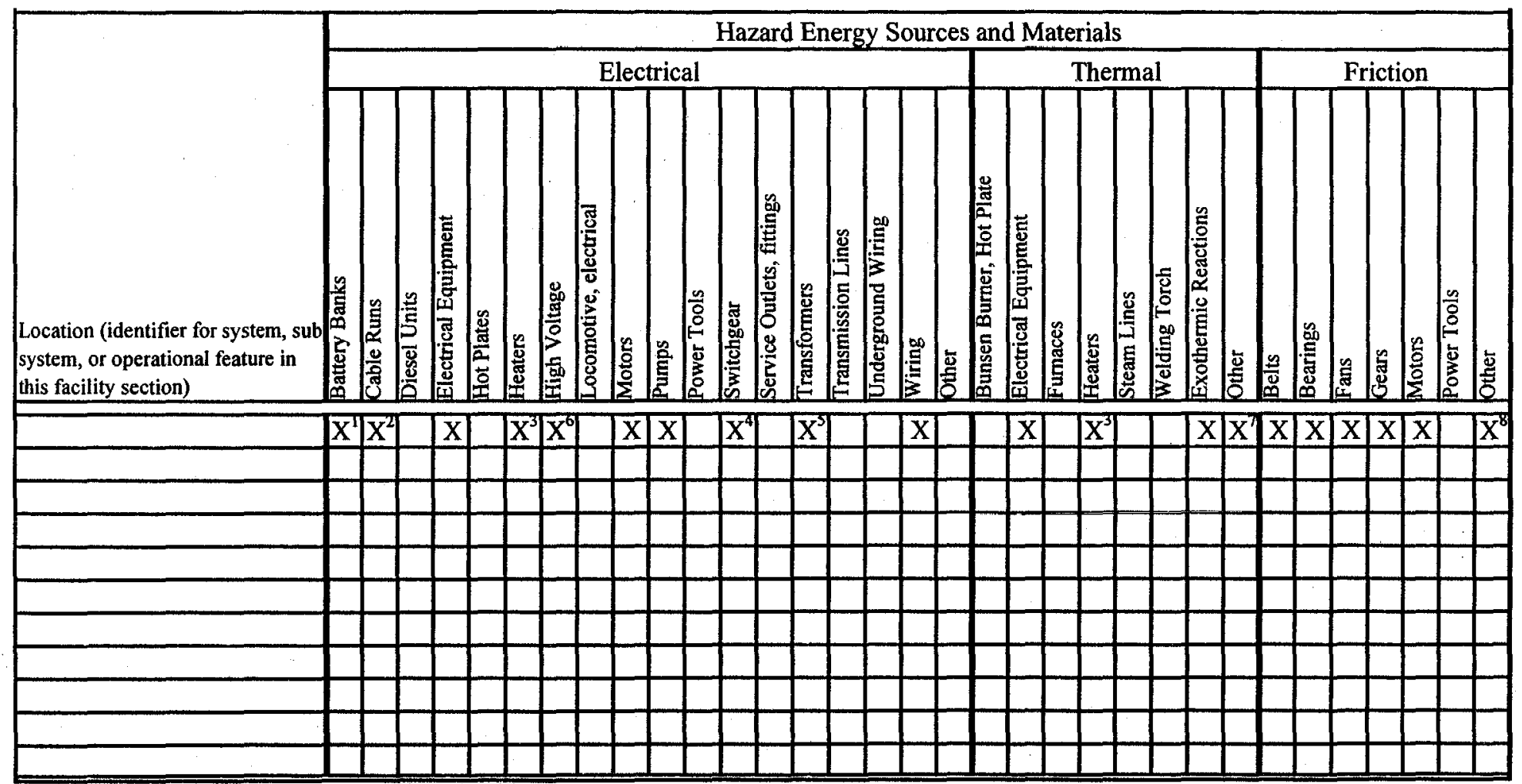

$\mathrm{X}=$ Refers to the hazards considered applicable

\section{FOOTNOTES:}

1. TWO FUEL BATTERIES, ONE ACCESSORY BATTERY

2. CABLES RUN THE LENGTH OF THE BUS, BELOW FLOOR AND OVERHEAD

3. ELECTRIC HEATING FOR PASSENGER COMPARTMENT

6. "HIGH VOLTAGE" 380V

4. RELAYS, CONROLLERS, RECTIFIERS

7. INTERNAL COMBUSTION ENGINE

8. BUS BRAKING SYSTEM

5. 12-110V TRANSFORMER 
Table 4. Hazard Identification Tables (cont.)

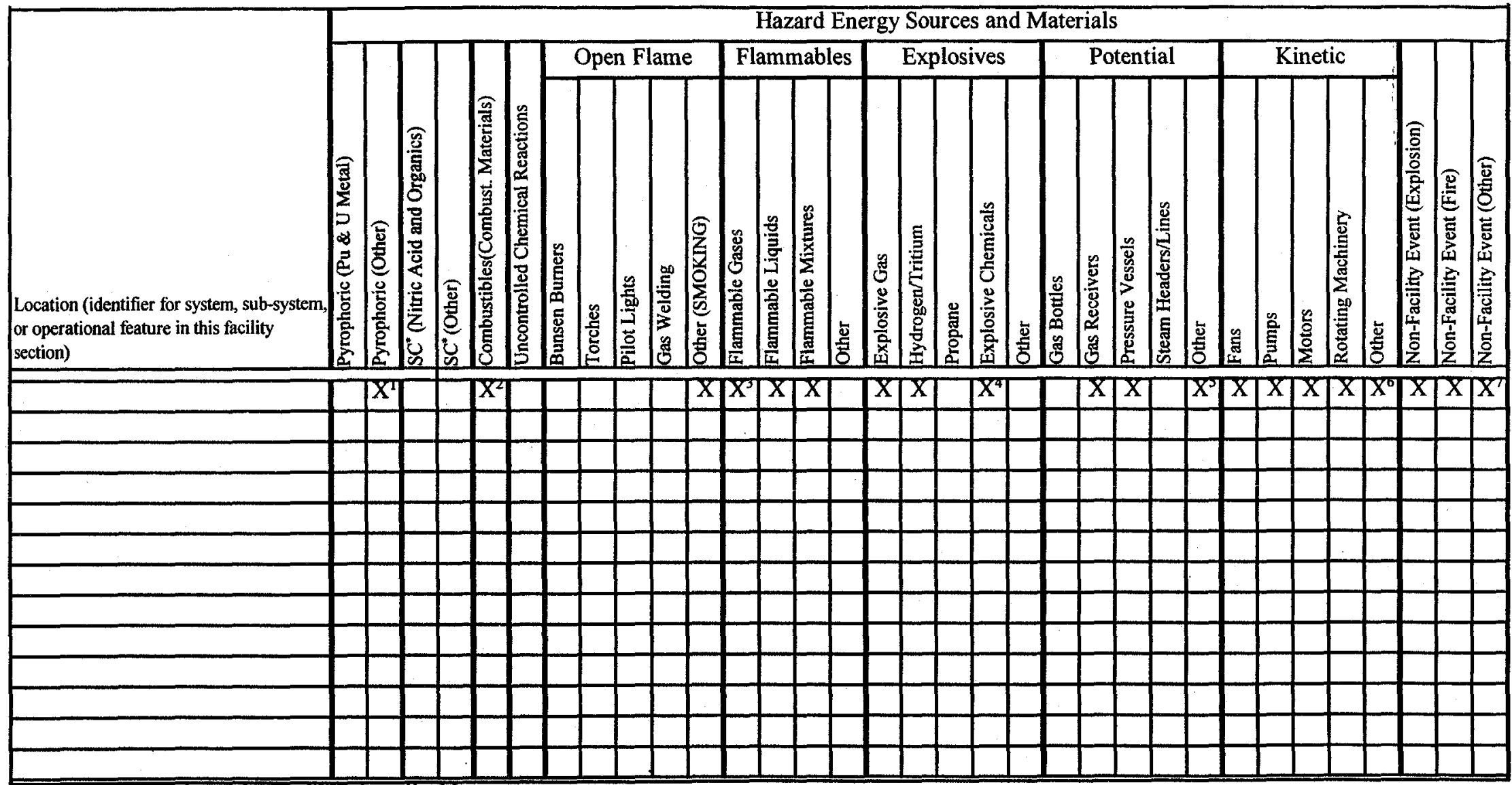

$\mathrm{X}=$ Reters to the hazards considered applicable

\section{FOOTNOTES:}

* SC=SPONTANEOUS COMBUSTION

1. CONTAMINATION OF HYDRIDE WITH AIR MAY PRODUCE HEAT

2. ETHYLENE GLYCOL, GENERAL COMBUSTIBLES, SERVICE FLUIDS,

HYDROGEN, LUBRICANTS, CRANK CASE OIL

3. FUEL AND BATTERIES

4. BATTERY CHEMICALS

5. HYDRAULIC SYSTEM, COOLANT SYSTEM, TIRES,

AC SYSTEM

6. MOTION OF VEHICLE

7. PROJECTILES (ROAD HAZARDS, DEBRIS, BULLET, ETC.) 
Table 4. Hazard Identification Tables (cont.)

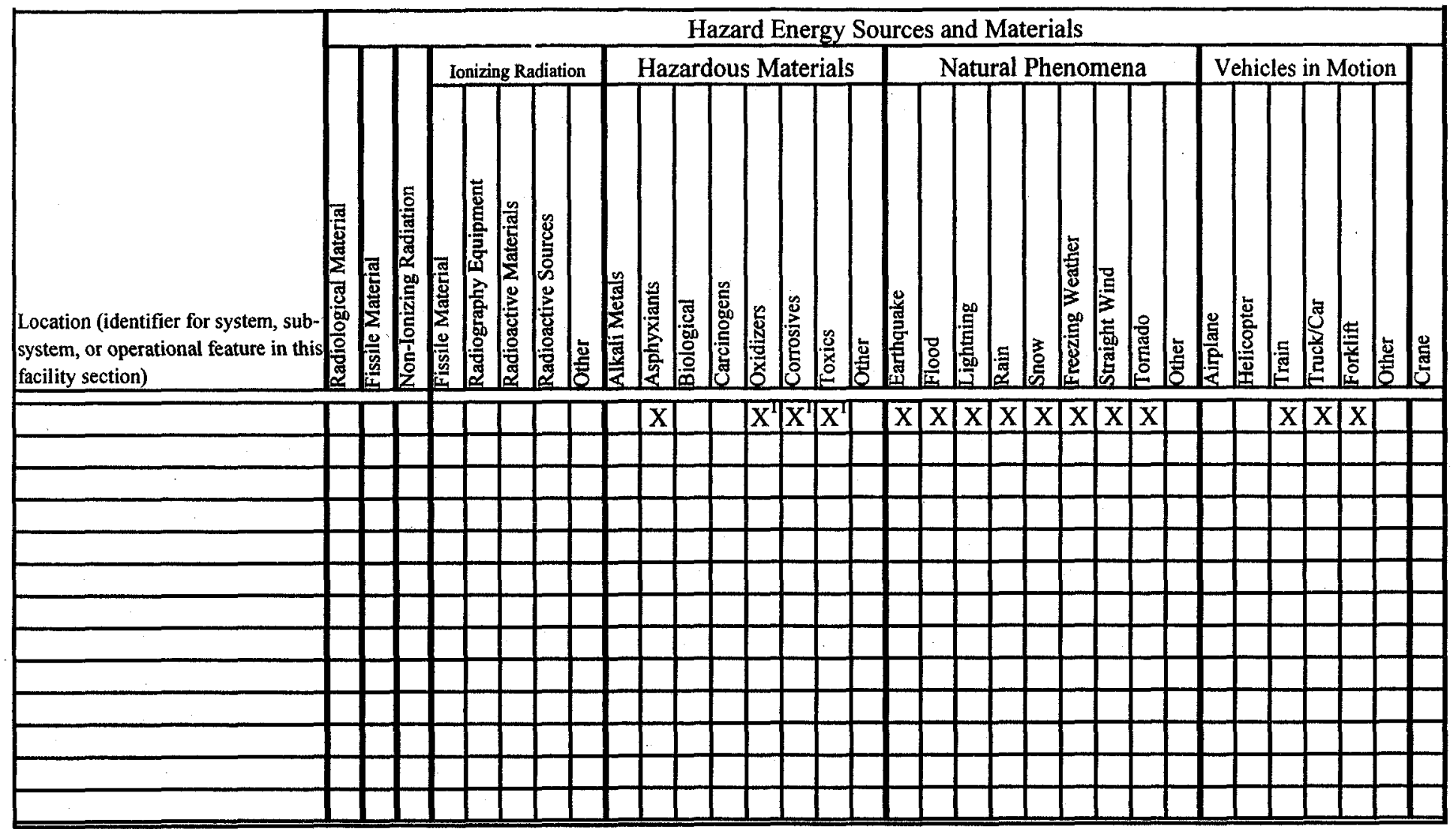

$\mathrm{X}=$ Refers to the hazards considered applicable

FOOTNOTES:

1. BATTERIES 
Table 5. Hazard Evaluation Tables

\begin{tabular}{|c|c|c|c|c|c|c|c|c|c|c|c|c|}
\hline \multirow[b]{2}{*}{$\begin{array}{l}\text { Event } \\
\text { No. }\end{array}$} & \multirow[b]{2}{*}{$\begin{array}{l}\text { Event } \\
\text { Cate- } \\
\text { gory }\end{array}$} & \multirow[b]{2}{*}{$\begin{array}{l}\text { Postulated Event } \\
\text { Description }\end{array}$} & \multirow[b]{2}{*}{ Causes } & \multicolumn{2}{|c|}{ Preventive features } & \multirow[b]{2}{*}{$\begin{array}{c}\text { Freq. } \\
\text { Level } \\
\& \\
\text { Source }\end{array}$} & \multirow[b]{2}{*}{$\begin{array}{l}\text { Method of } \\
\text { detection }\end{array}$} & \multicolumn{2}{|c|}{ Mitigative features } & \multicolumn{2}{|c|}{ Consequence level } & \multirow[b]{2}{*}{$\begin{array}{l}\text { Risk Bin } \\
\text { No. }\end{array}$} \\
\hline & & & & Design & Administrative & & & Design & Administrative & $\begin{array}{c}\text { Impact on other } \\
\text { systems }\end{array}$ & $\begin{array}{l}\text { Health and } \\
\text { Safety }\end{array}$ & \\
\hline 1 & $\overline{E-1}$ & $\begin{array}{l}\text { Fire involving general } \\
\text { combustibles, initiates } \\
\text { in passenger } \\
\text { compartment, bus } \\
\text { engulfed, hydrogen } \\
\text { not ignited }\end{array}$ & $\begin{array}{l}\text { Electrical short; } \\
\text { Cigar/cigarette } \\
\text { Smoking; } \\
\text { Electrical } \\
\text { heaters; } \\
\text { Unknown/misc. } \\
\text { ignition source; } \\
\text { Improper } \\
\text { maintenance; } \\
\text { Extemal event } \\
\end{array}$ & System design; & $\begin{array}{l}\text { Design } \\
\text { standards; } \\
\text { Operating \& } \\
\text { maintenance } \\
\text { procedures; } \\
\text { Smoking } \\
\text { restrictions }\end{array}$ & EU & $\begin{array}{l}\text { Visual; } \\
\text { Smell; }\end{array}$ & $\begin{array}{l}\text { Bus design; } \\
\text { Emergency } \\
\text { exits; Fire } \\
\text { extinguishers }\end{array}$ & $\begin{array}{l}\text { Passenger } \\
\text { evacuation }\end{array}$ & & $\begin{array}{|ll|}\text { Populace- } & \mathbf{M} \\
\text { Property- } & \mathbf{M} \\
\end{array}$ & 8 \\
\hline 2 & E-1 & $\begin{array}{l}\text { Fire involving general } \\
\text { combustibles, initiates } \\
\text { in passerger } \\
\text { compartment, bus } \\
\text { engulfed, hydrogen is } \\
\text { ignited }\end{array}$ & \begin{tabular}{|l|} 
Electrical short; \\
Cigar/cigarette \\
Smoking; \\
Electrical \\
heaters; \\
Unknown/misc. \\
ignition source; \\
Improper \\
maintenance; \\
External event \\
\end{tabular} & System design; & \begin{tabular}{|l|} 
Design \\
standards; \\
Operating \& \\
maintenance \\
procedures; \\
Smoking \\
restrictions
\end{tabular} & EU & $\begin{array}{l}\text { Visual; } \\
\text { Smell; }\end{array}$ & $\begin{array}{l}\text { Bus design; } \\
\text { Emergency } \\
\text { exits; Fire } \\
\text { extinguishers }\end{array}$ & $\begin{array}{l}\text { Passenger } \\
\text { evacuation }\end{array}$ & & \begin{tabular}{|l|} 
Populace- \\
Property-
\end{tabular} & 7 \\
\hline 3 & $E-1$ & $\begin{array}{l}\text { Fire involving general } \\
\text { combustibles, initiates } \\
\text { in electrical and/or } \\
\text { mechanical systems } \\
\text { outside passenger } \\
\text { compartment, bus } \\
\text { engulfed, hydrogen } \\
\text { not ignited }\end{array}$ & \begin{tabular}{|l|} 
Electrical short; \\
Lightning; High \\
Temperature; IC \\
Engine Failure; \\
Electrical \\
heater; \\
Unknown/misc. \\
ignition source; \\
Improper \\
maintenance; \\
External event \\
\end{tabular} & System design; & \begin{tabular}{|l} 
Design \\
standards; \\
Operating \& \\
maintenance \\
procedures;
\end{tabular} & $\bar{U}$ & $\begin{array}{l}\text { Visual; } \\
\text { Smell; }\end{array}$ & $\begin{array}{l}\text { Bus design; } \\
\text { Emergency } \\
\text { exits; Fire } \\
\text { extinguishers }\end{array}$ & $\begin{array}{l}\text { Passenger } \\
\text { evacuation }\end{array}$ & & \begin{tabular}{|l|l|} 
Populace- & M \\
Property- & M
\end{tabular} & 5 \\
\hline 4 & $\overline{E-1}$ & $\begin{array}{l}\text { Fire involving general } \\
\text { combustibles, initiates } \\
\text { in electrical and/or } \\
\text { mechanical systems } \\
\text { outside passenger } \\
\text { compartment, bus } \\
\text { engulfed, hydrogen is } \\
\text { ignited }\end{array}$ & \begin{tabular}{|l|} 
Electrical short; \\
Lightning; High \\
Temperature; IC \\
Engine Failure; \\
Electrical \\
heater; \\
Unknown/misc. \\
ignition source; \\
Improper \\
maintenance; \\
External event
\end{tabular} & System design; & \begin{tabular}{|l} 
Design \\
standards; \\
Operating \& \\
maintenance \\
procedures
\end{tabular} & $\bar{U}$ & $\begin{array}{l}\text { Visual; } \\
\text { Smell; }\end{array}$ & $\begin{array}{l}\text { Bus design; } \\
\text { Emergency } \\
\text { exits; Fire } \\
\text { extinguishers }\end{array}$ & $\begin{array}{l}\text { Passenger } \\
\text { evacuation }\end{array}$ & & \begin{tabular}{|l|} 
Populace- \\
Property-
\end{tabular} & 4 \\
\hline
\end{tabular}


Table 5. Hazard Evaluation Tables (cont.)

\begin{tabular}{|c|c|c|c|c|c|c|c|c|c|c|c|c|}
\hline \multirow[b]{2}{*}{$\begin{array}{l}\text { Event } \\
\text { No. }\end{array}$} & \multirow[b]{2}{*}{$\begin{array}{l}\text { Event } \\
\text { Cate- } \\
\text { gory }\end{array}$} & \multirow[b]{2}{*}{$\begin{array}{l}\text { Postulated Event } \\
\text { Description }\end{array}$} & \multirow[b]{2}{*}{ Causes } & \multicolumn{2}{|c|}{ Preventive features } & \multirow[b]{2}{*}{$\begin{array}{l}\text { Freq. } \\
\text { Level } \\
\& \\
\text { Source }\end{array}$} & \multirow[b]{2}{*}{$\begin{array}{l}\text { Method of } \\
\text { detection }\end{array}$} & \multicolumn{2}{|c|}{ Mitigative features } & \multicolumn{2}{|c|}{ Consequence level } & \multirow[b]{2}{*}{$\begin{array}{c}\text { Risk Bin } \\
\text { No. }\end{array}$} \\
\hline & & & & Design & Administrative & & & Design & Administrative & $\begin{array}{l}\text { Impact on other } \\
\text { systems }\end{array}$ & $\begin{array}{l}\text { Health and } \\
\text { Safety }\end{array}$ & \\
\hline 5 & $\overline{\mathrm{E}-\mathrm{l}}$ & $\begin{array}{l}\text { Fire due to leaked } \\
\text { hydrogen exposed to } \\
\text { ignition source }\end{array}$ & \begin{tabular}{|l|} 
Electrical short; \\
Cigar/cigarette \\
Smoking; \\
Electrical \\
heaters; \\
Unknown/misc. \\
ignition source; \\
Improper \\
maintenance; \\
Extemal event \\
\end{tabular} & System design; & \begin{tabular}{|l} 
Design \\
standards; \\
Operating \& \\
maintenance \\
procedures; \\
Smoking \\
restrictions
\end{tabular} & $\overline{\mathrm{U}}$ & $\begin{array}{l}\text { Visual; } \\
\text { Smell; }\end{array}$ & $\begin{array}{l}\text { Bus design; } \\
\text { Emergency } \\
\text { exits; Fire } \\
\text { extinguishers }\end{array}$ & $\begin{array}{l}\text { Passenger } \\
\text { evacuation }\end{array}$ & & $\begin{array}{ll}\text { Populace- } & \text { L } \\
\text { Property- } & \text { L }\end{array}$ & 6 \\
\hline 6 & $\overline{\mathrm{E}-2}$ & $\begin{array}{l}\text { Energetic failure of } \\
\text { hydrogen fuel system } \\
\text { causes damage and } \\
\text { injuries }\end{array}$ & $\begin{array}{l}\text { Improper } \\
\text { maintenance; } \\
\text { Mechanical } \\
\text { failure; Metal } \\
\text { fatigue; External } \\
\text { event }\end{array}$ & $\begin{array}{l}\text { System design; } \\
\text { Pressure relief } \\
\text { systems }\end{array}$ & $\begin{array}{l}\text { Design } \\
\text { standards; } \\
\text { Maintenance } \\
\text { procedures }\end{array}$ & $\overline{\mathrm{EU}}$ & $\begin{array}{l}\text { Visual; } \\
\text { Sound }\end{array}$ & $\begin{array}{l}\text { Passenger deck } \\
\text { (shielding) }\end{array}$ & & & 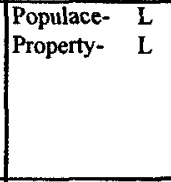 & 9 \\
\hline 7 & $\overline{E-2}$ & $\begin{array}{l}\text { Energetic failure of IC } \\
\text { engine causes damage } \\
\text { and injuries }\end{array}$ & $\begin{array}{l}\text { Improper } \\
\text { maintenance; } \\
\text { Mechanical } \\
\text { failure; Metal } \\
\text { fatigue; External } \\
\text { event }\end{array}$ & $\begin{array}{l}\text { System design; } \\
\text { Pressure relief } \\
\text { systems }\end{array}$ & \begin{tabular}{|l} 
Design \\
standards; \\
Maintenance \\
procedures
\end{tabular} & EU & $\begin{array}{l}\text { Visual; } \\
\text { Sound }\end{array}$ & \begin{tabular}{|l} 
Passenger deck \\
(shielding)
\end{tabular} & & & 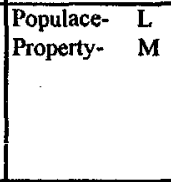 & 8 \\
\hline 8 & $\bar{E}-2$ & $\begin{array}{l}\text { Energetic failure of } \\
\text { hydraulic systems } \\
\text { (A/C, steering, } \\
\text { brakes,...) causes } \\
\text { damage and injuries }\end{array}$ & $\begin{array}{l}\text { Improper } \\
\text { maintenance; } \\
\text { Mechanical } \\
\text { failure; Metal } \\
\text { fatigue; External } \\
\text { event }\end{array}$ & $\begin{array}{l}\begin{array}{l}\text { System design; } \\
\text { Pressure relief } \\
\text { systems }\end{array} \\
\end{array}$ & \begin{tabular}{|l} 
Design \\
standards; \\
Maintenance \\
procedures
\end{tabular} & $\bar{U}$ & $\begin{array}{l}\text { Visual; } \\
\text { Sound }\end{array}$ & \begin{tabular}{|l|}
$\begin{array}{l}\text { Passenger deck } \\
\text { (shielding) }\end{array}$ \\
\end{tabular} & & & \begin{tabular}{|ll} 
Populace- & M \\
Property- & M
\end{tabular} & 5 \\
\hline 9 & $\overline{\mathrm{E}-2}$ & $\begin{array}{l}\text { Explosive gases from } \\
\text { fuel batteries and } \\
\text { accessory battery } \\
\text { collects and ignites }\end{array}$ & \begin{tabular}{|l|} 
Improper \\
maintenance; \\
Equipment \\
failure; External \\
Event (see \\
events $1 \& 2$ for \\
ignition sources)
\end{tabular} & Battery design & \begin{tabular}{|l|} 
Maintenance \\
procedures
\end{tabular} & $\mathrm{EU}$ & $\begin{array}{l}\text { Visual; } \\
\text { Sound }\end{array}$ & $\begin{array}{l}\begin{array}{l}\text { Passenger deck } \\
\text { (shielding) }\end{array} \\
\text { (a) }\end{array}$ & $\begin{array}{l}\text { Passenger } \\
\text { evacuation }\end{array}$ & & \begin{tabular}{|ll} 
Populace- & L \\
Property- & L
\end{tabular} & 9 \\
\hline 10 & $\overline{\mathrm{E}}-2$ & $\begin{array}{l}\text { IC Engine overheats } \\
\text { causing overpressure } \\
\text { or uncontrolled } \\
\text { hydrogen generation } \\
\text { from hydride beds }\end{array}$ & $\begin{array}{l}\text { Improper } \\
\text { maintenance; } \\
\text { Mechanical } \\
\text { failure }\end{array}$ & Engine design & $\begin{array}{l}\text { Design } \\
\text { standards; } \\
\text { Maintenance } \\
\text { procedures }\end{array}$ & $\overline{\mathrm{EU}}$ & $\begin{array}{l}\text { Visual; } \\
\text { Sound }\end{array}$ & $\begin{array}{l}\text { Overpressure } \\
\text { protection in } \\
\text { fuel system }\end{array}$ & & & $\begin{array}{ll}\text { Populace- } & \text { L } \\
\text { Property- } & \text { L }\end{array}$ & 9 \\
\hline
\end{tabular}


Table 5. Hazard Evaluation Tables (cont.)

\begin{tabular}{|c|c|c|c|c|c|c|c|c|c|c|c|c|}
\hline \multirow[b]{2}{*}{$\begin{array}{l}\text { Event } \\
\text { No. }\end{array}$} & \multirow[b]{2}{*}{$\begin{array}{l}\text { Event } \\
\text { Cate- } \\
\text { gory }\end{array}$} & \multirow[b]{2}{*}{$\begin{array}{l}\text { Postulated Event } \\
\text { Description }\end{array}$} & \multirow[b]{2}{*}{ Causes } & \multicolumn{2}{|c|}{ Preventive features } & \multirow[b]{2}{*}{$\begin{array}{l}\text { Freq. } \\
\text { Level } \\
\& \\
\text { Source }\end{array}$} & \multirow[b]{2}{*}{$\begin{array}{c}\text { Method of } \\
\text { detection }\end{array}$} & \multicolumn{2}{|c|}{ Mitigative features } & \multicolumn{2}{|c|}{ Consequence level } & \multirow[b]{2}{*}{$\begin{array}{l}\text { Risk Bin } \\
\text { No. }\end{array}$} \\
\hline & & & & Design & Administrative & & & Design & Administrative & $\begin{array}{c}\text { Impact on other } \\
\text { systems }\end{array}$ & $\begin{array}{l}\text { Health and } \\
\text { Safety }\end{array}$ & \\
\hline 11 & $\overline{E-2}$ & $\begin{array}{l}\text { Misstimed IC engine } \\
\text { combustion cycle } \\
\text { forces fuei/air mixture } \\
\text { back into fuel system, } \\
\text { spark plug ignites } \\
\text { with intake valve } \\
\text { open causing } \\
\text { explosion }\end{array}$ & $\begin{array}{l}\text { Improper } \\
\text { maintenance; } \\
\text { Mechanical } \\
\text { failure } \\
\end{array}$ & Engine design & $\begin{array}{l}\text { Design } \\
\text { standards; } \\
\text { Maintenance } \\
\text { procedures }\end{array}$ & EU & $\begin{array}{l}\text { Visual; } \\
\text { Sound }\end{array}$ & $\begin{array}{l}\text { Overpressure } \\
\text { protection in } \\
\text { fuel system }\end{array}$ & & & $\begin{array}{ll}\text { Populace- } & \text { L } \\
\text { Property- } & \text { L }\end{array}$ & 9 \\
\hline 12 & $\overline{E-2}$ & $\begin{array}{l}\text { Deflagration due to } \\
\text { leaked hydrogen } \\
\text { exposed to ignition } \\
\text { source w/o fire } \\
\text { propagation }\end{array}$ & \begin{tabular}{|l|} 
Improper \\
maintenance; \\
Mechanical \\
failure; \\
Equipment \\
failure; External \\
Event (see \\
events 1\&2 for \\
ignition sources)
\end{tabular} & System design & $\begin{array}{l}\text { Design } \\
\text { standards; } \\
\text { Maintenance } \\
\text { procedures }\end{array}$ & $\overline{0}$ & $\begin{array}{l}\text { Visual; } \\
\text { Sound }\end{array}$ & $\begin{array}{l}\text { Hydrogen leak } \\
\text { detection }\end{array}$ & & & \begin{tabular}{|ll} 
Populace- & L \\
Property- & L
\end{tabular} & 6 \\
\hline$\overline{13}$ & $\overline{\mathrm{E}-2}$ & $\begin{array}{l}\text { Detonation due to } \\
\text { leaked hydrogen } \\
\text { exposed to ignition } \\
\text { source }\end{array}$ & \begin{tabular}{|l|} 
Improper \\
maintenance; \\
Mechanical \\
failure; \\
Equipment \\
failure; External \\
Event (see \\
events $1 \& 2$ for \\
ignition sources)
\end{tabular} & System design & $\begin{array}{l}\text { Design } \\
\text { standards; } \\
\text { Maintenance } \\
\text { procedures }\end{array}$ & EU & $\begin{array}{l}\text { Visual; } \\
\text { Sound }\end{array}$ & $\begin{array}{l}\text { Hydrogen leak } \\
\text { detection }\end{array}$ & & & $\begin{array}{ll}\text { Populace- } & \text { H } \\
\text { Property- } & \text { H }\end{array}$ & 7 \\
\hline 14 & $\overline{E-3}$ & $\begin{array}{l}\text { Confinement lost in } \\
\text { hydrogen fuel header, } \\
\text { hydrogen leaks to } \\
\text { atmosphere, air leaks } \\
\text { into fuel system }\end{array}$ & $\begin{array}{l}\text { Improper } \\
\text { maintenance; } \\
\text { Mechanical } \\
\text { failure; } \\
\text { Equipment } \\
\text { failure; } \\
\text { Mechanical } \\
\text { failure; External } \\
\text { Event }\end{array}$ & System design & $\begin{array}{l}\text { Design } \\
\text { standards; } \\
\text { Maintenance } \\
\text { procedures }\end{array}$ & $\bar{U}$ & $\begin{array}{l}\text { Visual; } \\
\text { Sound }\end{array}$ & $\begin{array}{l}\text { Hydrogen leak } \\
\text { detection }\end{array}$ & & & $\begin{array}{l}\begin{array}{l}\text { Populace- } \\
\text { Property- }\end{array} \\
\text { Pols }\end{array}$ & 12 \\
\hline 15 & $\mathrm{E}-3$ & $\begin{array}{l}\text { Hydrogen leaks to } \\
\text { aluminum hydride bed } \\
\text { shroud (causes } \\
\text { potential for fire \& } \\
\text { explosion) }\end{array}$ & \begin{tabular}{|l|} 
Mechanical \\
failure; \\
Equipment \\
failure; \\
Improper \\
maintenance; \\
External event;
\end{tabular} & System design & $\begin{array}{l}\text { Design } \\
\text { standards; } \\
\text { Maintenance } \\
\text { procedures }\end{array}$ & $\bar{U}$ & $\begin{array}{l}\text { Visual; } \\
\text { Sound }\end{array}$ & $\begin{array}{l}\text { Hydrogen leak } \\
\text { detection }\end{array}$ & & & $\begin{array}{ll}\text { Populace- } & N \\
\text { Property- } & N\end{array}$ & 12 \\
\hline
\end{tabular}


Table 5. Hazard Evaluation Tables (cont.)

\begin{tabular}{|c|c|c|c|c|c|c|c|c|c|c|c|c|}
\hline \multirow[b]{2}{*}{$\begin{array}{l}\text { Event } \\
\text { No. }\end{array}$} & \multirow[b]{2}{*}{$\begin{array}{l}\text { Event } \\
\text { Cate- } \\
\text { gory }\end{array}$} & \multirow[b]{2}{*}{$\begin{array}{l}\text { Postulated Event } \\
\text { Description }\end{array}$} & \multirow[b]{2}{*}{ Causes } & \multicolumn{2}{|c|}{ Preventive features } & \multirow[b]{2}{*}{$\begin{array}{c}\text { Freq. } \\
\text { Level } \\
\& \\
\text { Source }\end{array}$} & \multirow[b]{2}{*}{$\begin{array}{l}\text { Method of } \\
\text { detection }\end{array}$} & \multicolumn{2}{|c|}{ Mitigative features } & \multicolumn{2}{|c|}{ Consequence level } & \multirow[b]{2}{*}{$\begin{array}{l}\text { Risk Bin } \\
\text { No. }\end{array}$} \\
\hline & & & & Design & Administrative & & & Design & Administrative & $\begin{array}{l}\text { Impact on other } \\
\text { systems }\end{array}$ & $\begin{array}{l}\text { Health and } \\
\text { Safety }\end{array}$ & \\
\hline$\overline{16}$ & E-3 & $\begin{array}{l}\text { Hydrogen leaks to } \\
\text { atmosphere (causes } \\
\text { potential for fire, } \\
\text { explosion, } \\
\text { asphyxiation, etc.) }\end{array}$ & $\begin{array}{l}\text { Mechanical } \\
\text { failure; } \\
\text { Equipment } \\
\text { failure; } \\
\text { Improper } \\
\text { maintenance; } \\
\text { External event; } \\
\end{array}$ & System design & $\begin{array}{l}\text { Design } \\
\text { standards; } \\
\text { Maintenance } \\
\text { procedures }\end{array}$ & $\mathrm{U}$ & $\begin{array}{l}\text { Visual; } \\
\text { Sound }\end{array}$ & $\begin{array}{l}\text { Hydrogen leak } \\
\text { detection }\end{array}$ & & & $\begin{array}{ll}\text { Populace- } & \text { N } \\
\text { Property- } & \text { N }\end{array}$ & 12 \\
\hline 17 & E-3 & $\begin{array}{l}\text { Air leaks into } \\
\text { depressurized } \\
\text { hydrogen system } \\
\text { (causes potential for } \\
\text { fire \& explosion) }\end{array}$ & \begin{tabular}{|l} 
Mechanical \\
failure; \\
Equipment \\
failure; \\
Improper \\
maintenance; \\
External event; \\
\end{tabular} & System design & \begin{tabular}{|l} 
Design \\
standards; \\
Maintenance \\
procedures
\end{tabular} & $\overline{\mathrm{U}}$ & $\begin{array}{l}\text { Visual; } \\
\text { Sound }\end{array}$ & & & & $\begin{array}{ll}\text { Populace- } & \mathrm{N} \\
\text { Property- } & \mathrm{N}\end{array}$ & 12 \\
\hline$\overline{18}$ & $E-4$ & $\begin{array}{l}\text { Person(s) asphyxiated } \\
\text { by leaked, } \\
\text { accumulated hydrogen }\end{array}$ & \begin{tabular}{|l} 
Mechanical \\
failure; \\
Equipment \\
failure; \\
Improper \\
maintenance; \\
Extemal event; \\
\end{tabular} & System design & $\begin{array}{l}\text { Design } \\
\text { standards; } \\
\text { Maintenance } \\
\text { procedures }\end{array}$ & $\mathrm{U}$ & $\begin{array}{l}\text { Visual; } \\
\text { Sound }\end{array}$ & $\begin{array}{l}\text { Hydrogen leak } \\
\text { detection }\end{array}$ & & & $\begin{array}{ll}\text { Populace- } & \text { H } \\
\text { Property- } & \text { N }\end{array}$ & $\overline{4}$ \\
\hline 19 & $E-4$ & $\begin{array}{l}\text { Person(s) injured by } \\
\text { invisible hydrogen } \\
\text { flame in fuel system }\end{array}$ & $\begin{array}{l}\text { Mechanical } \\
\text { failure; } \\
\text { Equipment } \\
\text { failure; } \\
\text { Improper } \\
\text { maintenance; } \\
\text { Extermal event; }\end{array}$ & System design & \begin{tabular}{|l} 
Design \\
standards; \\
Maintenance \\
procedures
\end{tabular} & $\overline{\mathrm{U}}$ & \begin{tabular}{|l} 
Visual; \\
Sound
\end{tabular} & $\begin{array}{l}\text { Hydrogen leak } \\
\text { detection }\end{array}$ & & & $\begin{array}{ll}\text { Populace- } & \text { M } \\
\text { Property- } & \text { L }\end{array}$ & 5 \\
\hline 20 & E-5 & $\begin{array}{l}\text { Collision causes rapid } \\
\text { hydrogen leak and } \\
\text { simultaneous ignition } \\
\text { source(s) (results in } \\
\text { fire, deflagration, or } \\
\text { detonation). }\end{array}$ & \begin{tabular}{|l|} 
Traffic accident \\
(i.e. Operator \\
error; \\
Mechanical \\
failure)
\end{tabular} & System design & \begin{tabular}{|l|} 
Design \\
standards; \\
Traffic Safety \\
Standards; \\
Maintenance \\
procedures \\
\end{tabular} & $\overline{\mathbf{U}}$ & $\begin{array}{l}\text { Visual; } \\
\text { Sound }\end{array}$ & & & & $\begin{array}{ll}\text { Populace- } & \text { H } \\
\text { Property- } & \text { H }\end{array}$ & 4 \\
\hline 21 & $\bar{E}-5$ & $\begin{array}{l}\text { Projectile (road } \\
\text { hazard, failed rotating } \\
\text { machinery, bullet, } \\
\text { etc.) damages } \\
\text { confinement \& safety } \\
\text { systems }\end{array}$ & $\begin{array}{l}\text { Mechanical } \\
\text { failure; } \\
\text { Equipment } \\
\text { failure; Road } \\
\text { hazard }\end{array}$ & System design & $\begin{array}{l}\text { Design } \\
\text { standards }\end{array}$ & $\overline{\mathrm{U}}$ & $\begin{array}{l}\text { Visual; } \\
\text { Sound }\end{array}$ & . & & & $\begin{array}{ll}\text { Populace- } & \text { L } \\
\text { Property- } & \text { L }\end{array}$ & 6 \\
\hline 22 & E-6 & $\begin{array}{l}\text { Extreme } \\
\text { environmental } \\
\text { conditions (freeze, } \\
\text { flood, etc.) damages } \\
\text { confinement \& safety } \\
\text { systems }\end{array}$ & \begin{tabular}{|l} 
Extreme \\
ambient \\
conditions;
\end{tabular} & System design & \begin{tabular}{|l|} 
Design \\
standards
\end{tabular} & $\bar{A}$ & $\begin{array}{l}\text { Visual; } \\
\text { Sound }\end{array}$ & & & & $\begin{array}{ll}\text { Populace- } & \text { N } \\
\text { Property- } & \text { L }\end{array}$ & 3 \\
\hline
\end{tabular}


Table 5. Hazard Evaluation Tables (cont.)

WSRC-RP-96-337, Rev. 0

\begin{tabular}{|c|c|c|c|c|c|c|c|c|c|c|c|c|}
\hline \multirow[b]{2}{*}{$\begin{array}{l}\text { Event } \\
\text { No. }\end{array}$} & \multirow[b]{2}{*}{$\begin{array}{l}\text { Event } \\
\text { Cate- } \\
\text { gory }\end{array}$} & \multirow[b]{2}{*}{$\begin{array}{l}\text { Postulated Event } \\
\text { Description }\end{array}$} & \multirow[b]{2}{*}{ Causes } & \multicolumn{2}{|c|}{ Preventive features } & \multirow[b]{2}{*}{$\begin{array}{c}\text { Freq. } \\
\text { Level } \\
\& \\
\text { Source }\end{array}$} & \multirow[b]{2}{*}{$\begin{array}{l}\text { Method of } \\
\text { detection }\end{array}$} & \multicolumn{2}{|c|}{ Mitigative features } & \multicolumn{2}{|c|}{ Consequence level } & \multirow[b]{2}{*}{$\begin{array}{l}\text { Risk Bin } \\
\text { No. }\end{array}$} \\
\hline & & & & Design & Administrative & & & Design & Administrative & $\begin{array}{c}\text { Impact on other } \\
\text { systerns }\end{array}$ & $\begin{array}{l}\text { Health and } \\
\text { Safety }\end{array}$ & \\
\hline$\overline{23}$ & E-6 & $\begin{array}{l}\text { Tomado, straight-line } \\
\text { winds, or resulting } \\
\text { missile damages bus } \\
\& \text { confinement } \\
\text { systems }\end{array}$ & Tomado & System design & $\begin{array}{l}\text { Design } \\
\text { standards }\end{array}$ & $\overline{\mathrm{U}}$ & $\begin{array}{l}\text { Visual; } \\
\text { Sound }\end{array}$ & & & & $\begin{array}{|ll|}\text { Populace- } & \text { M } \\
\text { Property- } & \text { M }\end{array}$ & 5 \\
\hline$\overline{24}$ & $\overline{E-6}$ & $\begin{array}{l}\text { Earthquake damages } \\
\text { bus and confinement } \\
\text { systems }\end{array}$ & Earthquake & System design & $\begin{array}{l}\text { Design } \\
\text { standards }\end{array}$ & $\bar{U}$ & $\begin{array}{l}\text { Visual; } \\
\text { Sound }\end{array}$ & & & & $\begin{array}{ll}\text { Populace- } & \text { M } \\
\text { Property- } & \text { M }\end{array}$ & 5 \\
\hline 25 & E-7 & $\begin{array}{l}\text { Hydrogen re-fueling } \\
\text { accident causes large } \\
\text { hydrogen release, } \\
\text { (creates potential for } \\
\text { fire/explosion) }\end{array}$ & $\begin{array}{l}\text { Operator error; } \\
\text { Maintenance } \\
\text { error }\end{array}$ & System design & $\begin{array}{l}\text { Maintenance } \\
\text { procedures; } \\
\text { Operating } \\
\text { procedures; } \\
\text { Design } \\
\text { standards } \\
\end{array}$ & A & $\begin{array}{l}\text { Visual; } \\
\text { Sound }\end{array}$ & & & & \begin{tabular}{|ll} 
Populace- & $\mathrm{N}$ \\
Property. & $\mathrm{N}$
\end{tabular} & 12 \\
\hline 26 & E-7 & $\begin{array}{l}\text { Maintenance error } \\
\text { compromises and/or } \\
\text { damages confinement } \\
\text { systems and safety } \\
\text { features }\end{array}$ & $\begin{array}{l}\text { Maintenance } \\
\text { error }\end{array}$ & 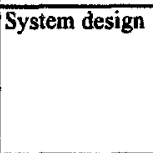 & $\begin{array}{l}\text { Maintenance } \\
\text { procedures; } \\
\text { Design } \\
\text { standards }\end{array}$ & A & Visual & & & & $\begin{array}{ll}\text { Populace- } & \text { N } \\
\text { Property- } & \text { L }\end{array}$ & 3 \\
\hline 27 & E-7 & $\begin{array}{l}\text { Total loss of power } \\
\text { compromises and/or } \\
\text { damages confinement } \\
\text { systems \& safety } \\
\text { features }\end{array}$ & \begin{tabular}{|l|} 
Electrical \\
failure; \\
Mechanical \\
failure; \\
Equipment \\
failure; Extemal \\
event; NPH \\
\end{tabular} & & $\begin{array}{l}\text { Maintenance } \\
\text { procedures; } \\
\text { Design } \\
\text { standards }\end{array}$ & $\bar{A}$ & Visual & & & & $\begin{array}{ll}\text { Populace- } & \mathrm{N} \\
\text { Property- } & \mathrm{L}\end{array}$ & 3 \\
\hline
\end{tabular}

Underlined preventive and/or mitigative features credited in determining frequency and/or consequence. 


\section{DISTRIBUTION:}

M.J. Hitchler $\quad 730-2 B$

S.R. Salaymeh 730-2B

L.A. Wooten

$730-2 \mathrm{~B}:$

D.J. Baker

$730-2 B$

J.W. Lightner

$730-2 \mathrm{~B}$

K.R. O'Kula

$730-2 \mathrm{~B}$

D.A. Coutts

$730-\mathrm{B}$

J.K. Thomas

$730-2 \mathrm{~B}$

A.G. Sarrack

$730-2 \mathrm{~B}$

D.P. Eisele

$730-2 \mathrm{~B}$

I.J. Paik

$730-2 \mathrm{~B}$

T.A. Long

$730-2 \mathrm{~B}$

W.J. Copeland

$730-2 \mathrm{~B}$

W.A. Summers

999-W

T. Motyka

773-A

L.K. Heung

773-A

T.L. Montgomery

703-46A

C.R. Meese

$730-1 \mathrm{~B}$

E. Gerstenberger

$730-1 \mathrm{~B}$

A.E. Blanchard

$730-1 B$

T. Wu

730-B

J. Handley

GTRI

F. Lynch

$\mathrm{HCI}$

W.C. Mosley

STC

G.L. Hovis

730-2B (20 extra copies) 


\section{WESTINGHOUSE SAVANNAH RIVER COMPANY \\ INTER-OFFICE MEMORANDUM}

June 21,1996

\section{TEMPORARY DELEGATION OF AUTHORITY}

Delegating Manager:

Department:

Title:
M. J. Hitchler

Safety Analysis \& Engineering Section

Manager

I hereby delegate my signature authority to L. A. Wooten for June 22-July 7, 1996 for the purpose of vacation time.

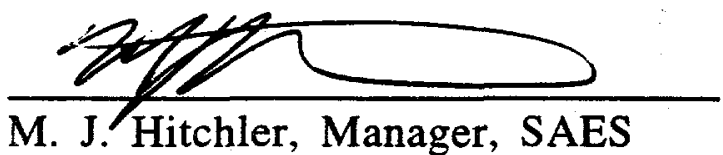

M. J. Hitchler, Manager, SAES

MJH:bcgr

CC. F. Beranek, 730-B

L. A. Wooten, 992W-1

D. J. Baker, 992W-1

S. R. Salaymeh, 992W-1

J. W. Lightner, 992W-1

D. A. Sharp, $992 \mathrm{~W}-1$

K. R. O'Kula, 992W-1 


\section{WESTINGHOUSE SAVANNAH RIVER COMPANY INTER-OFFICE MEMORANDUM}

\section{TEMPORARY DELEGATION OF AUTHORITY}

June 27, 1996

Delegating Manager: $\quad$ S. R. Salaymeh

Department Safety Engineering Department

Title: $\quad$ Manager, Environmental and Hazard Analysis

This is to delegate my signature authority to Ingle Paik for the period of $7 / 8 / 96$ through $7 / 12 / 96$. The purpose of my absence is for vacation.

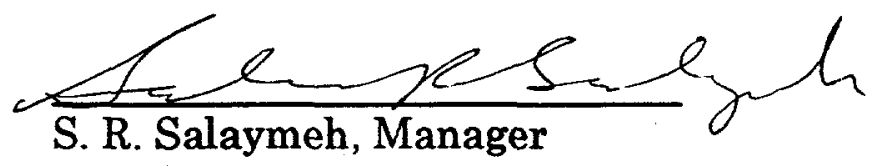

DJB/mla

F. Beranek, 730-B, Rm. 120

M. J. Hitchler, 730-2B
L. A. Wooten, 730-2B

K. R. O'Kula, 730-2B

J. W. Lightner, 730-2B

EAG Group 